\title{
A CASE STUDY
}

\section{Growth and opportunities of organized retailing in India}

\author{
GANESH DAS AND RITESH KALRA
}

Received : 23.01.2016; Accepted : 28.03.2016

\begin{abstract}
Retailing is one of the most attractive sector in the world's economy. It is becoming one of the largest industry all over the world. Indian economy is not also exception regarding this. From the last decades, the Indian retail industry has become the hot favourite destination for organized retail companies. A lot of big industrial groups have jumped in it as Reliance, Pantaloon, Tata, Landmark, Parimal, etc. Now the Indian retail sector has attracted the attention of people from various fields including academia and research organizations. The present study is undertaken to gain an insight about the present structure of Indian retail sector, the major sub-sectors in organized and traditional retail and changes in the relative share of organized retail in various segments. The study is descriptive in nature. The study is based on secondary data, which is taken from various reports published by various organizations.
\end{abstract}

KEY WORDS : Retailing, Organized retailing, Growth

How to cite this paper : Das, Ganesh and Kalra, Ritesh (2016). Growth and opportunities of organized retailing in India. Internat. J. Com. \& Bus. Manage, 9(1) : 108-112. 